\title{
THE IMPACT OF POSITIVE CASH OPERATING ACTIVITIES ON THE COST OF DEBT INTERNATIONAL EVIDENCE
}

\section{Dr. Saadani Ghali \\ Harit Satt}

Université Sidi Mohamed Ben Abdellah Faculté des Sciences Juridiques,, Economiques et Sociales - FES, Maroc

School of Business Administration, Al Akhawayn University, Ifrane

Doi: 10.19044/elp.v1no2a5 URL:http://dx.doi.org/10.19044/elp.v1no2a5

\begin{abstract}
This paper identifies the affiliation between the ending cash balance of the operating section in the cash flow statement and the bonds ratings. Our sample includes 600 companies from 26 countries. The study was conducted over a period of 18 years. An Ordered Probit regression analysis had been applied to identify how the positive cash balance of the operating section in the cash flow statement shapes the probability of escalating the bonds ratings. We find burly proof that the positive operating cash balance considerably affects the bonds ratings. In other words, when a company is able to generate enough cash from its main operating activities, the likelihood of having higher bonds ratings raises; this entails a low cost of debt since higher bond ratings have been proven to lessen the company's cost for raising funds (in the form of bonds). The results add more confirmation to the creditors' rights shields and how it affects the cost of debt.
\end{abstract}

Keywords: Credit ratings, operating cash position, default risk

\section{Introduction}

Information is the key to efficient functioning of the stock markets. Securities get priced correctly when the relevant information about companies get incorporated into the prices. Financial analysts play an important role in this process by bringing out new information about companies. Under normal circumstances, Stakeholders and more precisely creditors view analysts' research reports, forecasts, and recommendations as relatively accurate sources of information and use them in their rating 
decisions. In Brunnermeier and Pedersen (2009), for instance, a large market shock triggers the switch to a low liquidity, high margin equilibrium, where markets are illiquid, resulting in larger margin requirements. Previous studies identified the importance of cash management mechanisms and how beneficial they are to companies if applied properly. Acceptable level of liquidity should allow companies to have access to debt financing straightforwardly and at the lowest costs (interest). Having access to the financing sources at relatively low costs allows the company to gain a competitive advantage over others. This competitive advantage enables the company to boost its income since the costs for acquiring debts becomes low.

Cash management, which is perceived as one of the important mechanisms of good firm's performance, may play an important role in enhancing the positive image about the financial situation of the company. Very positive cash balances imply that the company is solvent and can meet its short term obligation without any liquidation costs. However, consulting the ending cash balance for the year (from the cashflow statement or the comparative balance sheet) can be sometimes misleading. Companies generate (use) cash from (in) three main activities: investing, financing and operating.

Investing activities includes every activity that is related to changes in tangible assets and more precisely long term assets (properties, plants and equipments). That is to say, a positive cash balance resulting from this section may cause questions to take place. If a company is generating cash from its operating activities, meaning that the company is selling its means of production (downsizing), a fact that is not appreciated by stakeholders and more precisely creditors.

Financing activities include any changes related to Long term debts (loans, bonds and notes payable) and stockholders equity. Under this section, positive cash balances mean that the company is raising capital either by writing-off bonds, acquiring loans or issuing stocks. A positive balance doesn't imply any information, unless one knows how this money was spent and how much it cost, keeping in mind the financial leverage and the ideal capital structure. On the other side, a negative cash balance in this section implies that the company is either repurchasing its own common shares outstanding or paying off its debt. Zeidan(2010) had claimed that in almost all cases, a negative cash ending balance in the financing section implies good signals; it means that the company has the cash requirement that enables it to meet its liabilities.

Last but not least, the operating section, which is the section of concern in this research. The net cash balance from this section, if positive, implies that the company is able to generate enough cash from its operating 
activities, so we have the right to not worry about the company's future, Amat (2013). On the other hand, if the ending cash balance of this section is negative, it implies that the company is not able to generate enough cash from its main operations; this will make all stakeholder worried about the company's future even in the short run.

From all the three sections discussed above, auditors and analysts base their companies' valuation mostly on the net cash generated from the operating activities. It does not mean that the financing and investing sections of the cashflow statement are useless, but it signifies that the operating section is more informative mainly because of the nature of activities and transactions that it encompasses, Ojo and Marianne (2013)

Positive cash balances results in positive signaling to all stakeholders, by implying that the company has the ability to meet all obligations and consequently reduces the external financing costs for companies. This is because, creditors, as well as shareholders, will know that the company can pay them back anytime and, hence, ask for lower returns since they have clearer ideas about the company's perspectives and liquidity risk levels. Actually, positive operating cash balance may have other impacts on a company. For example, if we prove that the positive operating cash balance affects positively companies' bonds ratings, we can conclude that low default risk leads to, relatively, lower costs of debt given that Kisgen and Strahan (2009) proved that higher ratings lead creditors to ask for lower returns. Actually, higher ratings of bonds were found to reduce the creditors' risk which is assigned to the company inability to pay back its debts (the default risk). As a result, the creditors' risk perception, for companies with high ratings, becomes lower and the company's cost of debt decreases since the creditors end up asking for relatively lower required returns. All in all, very few work related to the impact of cash management or default risk levels on companies' cost of debt has already taken place, but no study tried to explore the following hypothesis: do rating agencies value the operating cash balance of a company when rating firms' bonds? If our empirical results approve this hypothesis, we can conclude that the positive operating cash balance is another variable that leads to lower costs of debts.

Our goal is to empirically find out how operating cash balance of the cashflow statement affects the cost of debt for companies. More precisely, we intend to identify whether the rating agencies decisions to rate firms' bonds are affected by the company's operating cash position (whether negative or positive). Our study is similar in spirit to Hamdi et al. (2013) who study the value of the auditor choice and how it affects the corporate bond rating. 


\section{Literature review}

Information and good corporate governance is the key to efficient functioning of the stock markets. Securities get priced correctly when the relevant information about firms get incorporated into the prices. Financial analysts play an important role in this process by bringing out new information about firms, mainly their profitability and liquidity. Under normal circumstances, stock market participants view analysts' research reports, forecasts, and recommendations as relatively accurate sources of information and use them in their investment decisions. Jensen and Meckling (1976) suggest that, as information intermediaries, financial analysts are able to mitigate the agency problems present within firms. Merton (1987) argues that the market value of a firm is an increasing function of the breadth of investor awareness.

Berger (1995) has discovered a positive relationship between the return on equity and the ratios of capital to assets. He explained that by having higher capital ratio, the cost of funds on account and the quantity of funds required would be lower. As a result, the firm's net interest income will increase and thus the profitability too. On the other hand, Navapan and Tripe (2003) have concluded the opposite. They have found that a negative relationship between capital and profitability exists. Kontus (2012) explained that an increase of short-term debt leads to a decrease of profitability that is shown in terms of return assets.

Odders-White and Ready (2006) argued that companies with more liquidity have better credit quality than companies with less liquidity. Companies with high liquidity, they are less likely to default; "they have assets that they can use in case of emergency". The authors add, usually companies with more liquidity are always enjoying high quality credit terms and they always opt for more. From the side of creditors, mainly banks, good customers enjoy their privileges and they do their best not only to keep them, but they opt for more. In addition, Butler et al. (2005) discovered that liquidity affects the cost of issuing equity, and especially the direct cost of issuing debt. In other words, companies with higher liquidity have less risk, and thus lower interest rate. Oppositely, companies with lower liquidity have higher risk for return and therefore higher interest rate.

Deloof found that working capital management is considered one of the major components of corporate finance as it has a direct impact on companies' profitability and liquidity. Consequently, in order to create the highest shareholder value, having an efficient management of working capital would be primordial; in fact, most of companies try to maintain an ideal level of working capital that will boosts and raises their value (Deloof, 2003; Afza \& Nazir, 2007). However, Matuva (2010) found that there are 
some decisions that incline to increase the profitability and thus reduce the chances of suitable liquidity. Oppositely, if we focus only on liquidity, it may minimize the potential of companies' profitability. In addition, Lazaridis and Tryfonidis (2006) found that there is an arithmetical relationship between profitability that is measured through Gross Operating Profit, and the cash conversion cycle. They found that managers have the ability to create price for shareholders by handling suitably the cash conversion cycle and by maintaining each component to an optimum level.

\section{Liquidity and the Cost of Debt}

Different firm's specific parameters have been found to influence the company cost of debt. Jenzazi (2010) found that the company's cash management affects the cost of debt. In his paper, the cash management had been assigned a score from 0 to 4 on the basis of different criteria (refer to table 1 for more information about these criteria) and the results suggested that as the score increases the cost of debt decreases.

The above arguments lead us to the following testable hypothesis:

H1: Generating positive cash balance will reduce the company's cost of debt financing.

$\mathrm{H} 2$ : Generating positive net cash provided form operating activities leads to higher bonds ratings.

Our study will contribute to the scarce existing literature in several ways. First, we will try to assess the perception of the corporate bond market of the quality of the company's liquidity. Second, contrary to Jenzazi (2010) and the other studies, our study will focus on this issue in an international context. This will allow us to better understand the functioning of the different debt markets around the world. More importantly, this will give us the valuable opportunity to see how external governance mechanisms (such as the legal and extra-legal institutions) interact with the internal mechanisms (in our case cash generated from operating activities) to enhance the overall governance quality in one country.

\section{Methodology and Descriptive Statistics Specifications}

The purpose of this research is to study the relationship between the positive operating cash and the bonds ratings. In order to study the relationship between these two variables, the following general specification is going to be used:

Bond Rating $=\mathrm{f}$ (operating cash position, Issuer Characteristics, Issue Characteristics)

This model includes three major determinants (Operating cash position, Issuer Characteristics, and Issue Characteristics) of bond ratings. 
The issuer characteristics variables include the company profitability (measured by the company's return on assets, the company size which measured by the company total assets, the company risk that is measured by the company variability of earnings, and the leverage that is measured by the debt to equity ratio). The issue characteristics variables include the issue size or the size of the bonds, the bonds maturity, and the convertible provision (an option that gives the right to a bondholder to exchange the bonds for shares).

The ratings that are used for the bonds belong to seven different ordering categories (illustrated by the S\&P ratings). This implies that the Ordered Probit Model can be used since the bond rating is an ordinal variable.

\section{Data Sources and Variables}

Our sample includes 600 companies operating in different 26 countries. Table 2 gives a description of the sample and the distribution of the 600 observations. The observations are from 2002 to 2012. The S\&P credit ratings were used in order to get the bonds ratings. The ratings range from AAA to D and include 22 possible ratings. These ratings illustrate the creditworthiness of companies. In other words, they give an idea about company' abilities to repay back their loans obligations when they are due. As it is shown in Appendix A, the initial ratings that are suggested by $\mathrm{S} \& \mathrm{P}$ have been converted to ordering numbers ranging from 1 as being the lowest rating to 7 as being the highest rating. The ratings were converted on the basis of the research that was conducted by Ashbaugh, Collins, and LaFond (2006). The bonds ratings data was retrieved from F- Database.

\section{Table 2: Sample Description}

The panels below give a description of the sample that was used to derive the outputs. Panel

A specifies the countries that companys in the sample operate in. Panel B gives the distribution of the observation on a yearly basis (starting from 1996 to 2006). Panel $\mathrm{C}$ gives a description of the observations based on the industry.

\begin{tabular}{|l|l|l|l|l|l|l|}
\hline \multicolumn{2}{|l|}{$\begin{array}{l}\text { Panel A: Sample Distribution per } \\
\text { Country }\end{array}$} & \multicolumn{3}{l|}{ Panel B:Sample Distribution per Years } \\
\hline Country & Number & Percent & Years & Number & Percent \\
\hline & & & & & \\
\hline Argentina & 8 & 1.33 & 1996 & 2 & 0.33 \\
\hline Australia & 11 & 1.83 & 1997 & 23 & 3.83 \\
\hline Austria & 8 & 1.33 & 1998 & 22 & 3.67 \\
\hline Brazil & 23 & 3.83 & 1999 & 55 & 9.17 \\
\hline Canada & 136 & 22.67 & 2000 & 100 & 16.67 \\
\hline Chile & 7 & 1.17 & 2001 & 120 & 20.00 \\
\hline Colombia & 1 & 0.17 & 2002 & 122 & 20.33 \\
\hline Denmark & 7 & 1.17 & 2003 & 55 & 9.17 \\
\hline Finland & 7 & 1.17 & 2004 & 45 & 7.50 \\
\hline France & 23 & 3.83 & 2005 & 43 & 7.17 \\
\hline
\end{tabular}




\begin{tabular}{|l|l|l|l|l|l|l|}
\hline Germany & 35 & 5.83 & 2006 & 13 & 2.17 \\
\hline Hong Kong & 12 & 2.00 & Total & $\mathbf{6 0 0}$ & $\mathbf{1 0 0}$ \\
\hline Indonesia & 3 & 0.50 & & & & \\
\hline Israel & 4 & 0.67 & & & & \\
\hline Italy & 27 & 4.50 & & & \\
\hline Japan & 12 & 2.00 & & & \\
\hline Korea (South) & 22 & 3.67 & \multicolumn{2}{|l|}{$\begin{array}{l}\text { Panel C: Sample Distribution per } \\
\text { Industries }\end{array}$} \\
\hline Malaysia & 2 & 0.33 & Industry & Number & Percent \\
\hline Mexico & 14 & 2.33 & Manufacturing & 230 & 38.33 \\
\hline Netherlands & 13 & 2.17 & Transport & 10 & 1.67 \\
\hline New Zealand & 1 & 0.17 & Trades & 40 & 6.67 \\
\hline Norway & 6 & 1.00 & Financial Services & 243 & 40.50 \\
\hline Philippines & 6 & 1.00 & Utility & 77 & 12.83 \\
\hline Poland & 2 & 0.33 & Total & $\mathbf{6 0 0 . 0 0}$ & $\mathbf{1 0 0 . 0 0}$ \\
\hline Portugal & 10 & 1.67 & & & & \\
\hline Singapore & 10 & 1.67 & & & & \\
\hline South Africa & 1 & 0.17 & & & & \\
\hline Spain & 8 & 1.33 & & & \\
\hline Sweden & 19 & 3.17 & & & & \\
\hline Switzerland & 15 & 2.50 & & & & \\
\hline Taiwan & 13 & 2.17 & & & \\
\hline Thailand & 4 & 0.67 & & & & \\
\hline Turkey & 1 & 0.17 & & & & \\
\hline United Kingdom & 123 & 20.50 & & & & \\
\hline United States & 6 & 1.00 & & & & \\
\hline Total & $\mathbf{6 0 0}$ & $\mathbf{1 0 0 . 0 0}$ & & & & \\
\hline
\end{tabular}

The operating cash balance is a dummy variable which takes the value 1 if the company's operating cash balance is positive and 0 otherwise.

The issue and issuer variables are control variables that are added to the model in order to give more explanations related to the bonds ratings. Table 1 gives a detailed description of the variables that were used in our study. The data for the control variables was retrieved from W.S Database.

Table 1: Variables Description and Sources

\begin{tabular}{|l|l|l|}
\hline Variable & Description & Source \\
\hline Bonds Ratings & $\begin{array}{l}\text { Appendix A gives detailed information about this } \\
\text { ordinal variable. The bond ratings that are used by S\&P } \\
\text { are converted to a range from 1 to 7 where 1 is the } \\
\text { lowest rating and 7 the highest rating. The rating of } \\
\text { bonds depends on the company bonds portfolio. }\end{array}$ & F-Database \\
\hline $\begin{array}{l}\text { Company's } \\
\text { Cash balance }\end{array}$ & $\begin{array}{l}\text { A dummy variable that is assigned 1 if the company's } \\
\text { yearly operating cash balance is positive and 0 } \\
\text { otherwise. }\end{array}$ & W-S Database \\
\hline $\begin{array}{l}\text { Company } \\
\text { Profitability }\end{array}$ & $\begin{array}{l}\text { A variable that measures the profitability of the } \\
\text { company by dividing its net income to its total assets }\end{array}$ & W-S Database \\
\hline
\end{tabular}




\begin{tabular}{|c|c|c|}
\hline Company Size & $\begin{array}{l}\text { The company size is determined by its total assets in } \\
\text { dollar amounts. }\end{array}$ & W-S Database \\
\hline Company risk & $\begin{array}{l}\text { The company's risk is measured by the standard } \\
\text { deviation of the net income of every company in the } \\
\text { sample. }\end{array}$ & W-S Database \\
\hline Bonds Maturity & $\begin{array}{l}\text { A variable that measures the log maturity in years. The } \\
\text { weights are determined by the size of the issuance of } \\
\text { the maturity class to the total size of the issuance for a } \\
\text { given year. Then, the weights are multiplied to the } \\
\text { respective maturity and added to get the bonds } \\
\text { weighted average maturity. }\end{array}$ & W-S Database \\
\hline $\begin{array}{l}\text { Convertible } \\
\text { Provisions }\end{array}$ & $\begin{array}{l}\text { A dummy variable that gives } 1 \text { to companys with } \\
\text { convertible provisions and } 0 \text { to companys with no } \\
\text { convertible provisions. These provisions allow the } \\
\text { bondholder to convert his or her bonds to shares. }\end{array}$ & W-S Database \\
\hline Issue Size & A variable that identifies the size of the issuance. & W-S Database \\
\hline Leverage & $\begin{array}{l}\text { A variable that identifies the leverage of the company; } \\
\text { measured by dividing the company debts to its equity. }\end{array}$ & W-S Database \\
\hline $\begin{array}{l}\text { Creditors } \\
\text { Rights }\end{array}$ & $\begin{array}{l}\text { This variable is an index that ranges from } 0 \text { to } 4 \text {. When } \\
\text { a country imposes restrictions in the favor of creditors, } \\
1 \text { is added to its score. When the secured creditors } \\
\text { ensure that they will get their investment back, the } \\
\text { score becomes } 2 \text {. When the secured creditors are the } \\
\text { first to receive their money in case of bankruptcy, the } \\
\text { score becomes } 3 \text {. At the end, when the secured } \\
\text { creditors don't wait till the problems are solved to get } \\
\text { their money back, the score becomes } 4 \text {. }\end{array}$ & $\begin{array}{l}\text { Djankov et al. } \\
(2005)\end{array}$ \\
\hline Public Registry & $\begin{array}{l}\text { Public registry is a database that is developed by public } \\
\text { authorities. This database includes all the debt positions } \\
\text { of borrowers in the economy. The collected information } \\
\text { is available to all financial institutions. The variable is } \\
\text { assigned } 1 \text { if the country has a public registry and } 0 \\
\text { otherwise. }\end{array}$ & $\begin{array}{l}\text { Djankov et al. } \\
(2005)\end{array}$ \\
\hline $\begin{array}{l}\text { Efficiency of } \\
\text { Bankruptcy } \\
\text { Process }\end{array}$ & $\begin{array}{l}\text { When a company incurs bankruptcy costs, theses costs } \\
\text { are deducted from the company terminal value and this } \\
\text { value is discounted to get the present value. The higher } \\
\text { the value, the better the company. }\end{array}$ & $\begin{array}{l}\text { Djankov et al. } \\
(2007)\end{array}$ \\
\hline $\begin{array}{l}\text { News } \\
\text { Circulation }\end{array}$ & $\begin{array}{l}\text { Daily newspapers sold divided by the number of } \\
\text { citizens }\end{array}$ & $\begin{array}{l}\text { Dyck and } \\
\text { Zingales } \\
(2004)\end{array}$ \\
\hline Manufacturing & $\begin{array}{l}\text { Dummy variable that equals } 1 \text { if the company operates } \\
\text { in the Manufacturing industry; } 0 \text { otherwise }\end{array}$ & \\
\hline Trades & $\begin{array}{l}\text { Dummy variable that equals } 1 \text { if the company operates } \\
\text { in the Trades industry; } 0 \text { otherwise Trades }\end{array}$ & \\
\hline Finance & $\begin{array}{l}\text { Dummy variable that equals } 1 \text { if the company operates } \\
\text { in the Finance industry; } 0 \text { otherwise Finance }\end{array}$ & \\
\hline Utility & $\begin{array}{l}\text { Dummy variable that equals } 1 \text { if the company operates } \\
\text { in the Utility industry; } 0 \text { otherwise. }\end{array}$ & \\
\hline
\end{tabular}


The bonds ratings, the convertible provision, and the issue size (the issue characteristics) were computed following a portfolio approach as Anderson, Mansi and Reeb (2003) and Boubakri and Ghouma (2008) applied in their papers. The total company issues for every year were gathered and the size of the issue to the total issues was the weight that we used to compute the average bonds ratings, the convertible provision, and the issue size for every company over every year of the period of the study.

After defining the variables that are included in our model, the bond rating model can be expressed as the following:

Prob. (Bonds Ratings $=X)=F\left(b_{1}\right.$. operating cash position $+b_{2}$. Company Profitability $+b_{3}$. Company Size $+b_{4}$. Company Risk $+b_{5}$. Bonds Maturity $+b_{6}$. Convertible Provisions $+b_{7}$. Issue Size $+b_{8}$. Leverage + Institutional variables + Year Dummies+ Industry Dummies + ei); Where $X$ belongs to $\{1,2,3$, $4,5,6,7\}$

\section{Empirical Results}

Panel (A) in table 3 gives the descriptive statistics for the variables that were used in our study. The panel starts by the credit rating variable; the mean for this variable is 4.432 , which is equivalent to an S\&P rating of $\mathrm{BBB}+$.

\begin{tabular}{llll}
\hline \multicolumn{3}{c}{ Panel A: Descriptive Statistics } \\
\hline & Observations & Mean & $\begin{array}{l}\text { Standard } \\
\text { Deviation }\end{array}$ \\
\hline Bonds Ratings & & 4.432 & 1.321 \\
Cash position & 600 & 0.423 & 0.342 \\
Company Profitability & 600 & 4.134 & 23.543 \\
Company Size (in million of & 600 & 89.89 & 1.54 \\
U.S Dollars) & 600 & & \\
Company risk & 600 & $435,534.7$ & $654,087.3$ \\
Bonds Maturity (in years) & 600 & 6.43 & 0.543 \\
Convertible Provisions & 600 & 0.034 & 0.457 \\
Issue Size & 600 & $746,923.4$ & $4,687,234$ \\
Leverage & 600 & 432.367 & $1,432.674$ \\
\hline
\end{tabular}

The following descriptive statistics refer to the issuer characteristics variables that were used in our study. The operating cash position is the first variable and has a mean of 0.71 ; this means that around $71 \%$ of the companies that are included in the sample have a positive operating cash balance. Concerning the profitability of the companies, the mean average for the return on assets is 4.03. The mean of the company size was found to equal 65 million dollars; this was measured by averaging the total assets of the 600 companies that constitute the sample. 
Concerning the issuance variables, the mean average for the bonds maturity is 5.44 years. The second variable in this category is the convertible bonds option; the mean for this variable is $8.5 \%$ meaning that $8.5 \%$ of the companies have offered this option to their bondholders.

Panel (B1) from table 3 illustrates the correlation between our dependent variable (Bond Rating) and the operating cash position, the issue characteristics variables, and the issuer characteristics variables. The results demonstrate that different independent variables are significantly correlated with the bonds ratings. The operating cash position, the company performance, the company size, and the convertible option were found to be positively correlated to the bonds rating at significance levels of less than $1 \%$. The company leverage was found to be positively correlated at a significance level of 5\%. One variable (bonds maturity) was found to be negatively correlated with the Bond Ratings at a significance level of less than $1 \%$. The issue size and the company risk were found to be not significantly correlated to the bonds ratings.

Panel B1: Correlation between the operating cash position and Bonds Ratings =

\begin{tabular}{|c|c|c|c|c|c|c|c|c|c|}
\hline Variable & $\begin{array}{l}\text { Bonds } \\
\text { Ratings }\end{array}$ & $\begin{array}{l}\text { Cash } \\
\text { Position }\end{array}$ & $\begin{array}{l}\text { Company } \\
\text { Profit }\end{array}$ & $\begin{array}{l}\text { Company } \\
\text { Size }\end{array}$ & $\begin{array}{l}\text { Compa } \\
\text { ny risk }\end{array}$ & $\begin{array}{l}\text { Bonds } \\
\text { Maturity }\end{array}$ & $\begin{array}{l}\text { Convertib } \\
\text { le } \\
\text { Provision } \\
\mathrm{s}\end{array}$ & $\begin{array}{l}\text { Issue } \\
\text { Size }\end{array}$ & $\begin{array}{l}\text { Leve } \\
\text { rage }\end{array}$ \\
\hline $\begin{array}{l}\text { Bonds } \\
\text { Ratings } \\
\end{array}$ & 1.000 & & & & & & & & \\
\hline $\begin{array}{l}\text { Cash } \\
\text { position }\end{array}$ & $\begin{array}{l}0.1305 \\
(0.0016)^{* *} \\
*\end{array}$ & 1.000 & & & & & & & \\
\hline $\begin{array}{l}\text { Company } \\
\text { Profitabil } \\
\text { ity }\end{array}$ & $\begin{array}{l}0.1156 \\
(0.0006)^{* *} \\
*\end{array}$ & $\begin{array}{l}0.0568 \\
(0.02340) \\
* *\end{array}$ & 1.000 & & & & & & \\
\hline $\begin{array}{l}\text { Company } \\
\text { Size }\end{array}$ & $\begin{array}{l}0.3688 \\
(0.0005)^{* *} \\
*\end{array}$ & $\begin{array}{l}0.0543 \\
(0.0334)^{*}\end{array}$ & $\begin{array}{l}-0.1433 \\
(0.887)\end{array}$ & 1.000 & & & & & \\
\hline $\begin{array}{l}\text { Company } \\
\text { risk }\end{array}$ & $\begin{array}{l}0.0209 \\
(0.4534)\end{array}$ & $\begin{array}{l}-0.0432 \\
(0.3645)\end{array}$ & $\begin{array}{l}-0.0366 \\
(0.5976)\end{array}$ & $\begin{array}{l}0.6789 \\
(0.0004)^{*} \\
* *\end{array}$ & 1.000 & & & & \\
\hline $\begin{array}{l}\text { Bonds } \\
\text { Maturity }\end{array}$ & $\begin{array}{l}-0.2345 \\
(0.0003)^{* *} \\
*\end{array}$ & $\begin{array}{l}0.321 \\
(0.2342)\end{array}$ & $\begin{array}{l}-0.0033 \\
(0.8766)\end{array}$ & $\begin{array}{l}-0.3456 \\
(0.0000)^{*} \\
* *\end{array}$ & $\begin{array}{l}-0.0854 \\
(0.4434 \\
)\end{array}$ & 1.000 & & & \\
\hline $\begin{array}{l}\text { Convertib } \\
\text { le } \\
\text { Provision } \\
\mathrm{s}\end{array}$ & $\begin{array}{l}0.2345 \\
(0.0000)^{* * *} \\
*\end{array}$ & $\begin{array}{l}0.0322 \\
(0.6300)\end{array}$ & $\begin{array}{l}0.0543 \\
(0.5324)\end{array}$ & $\begin{array}{l}-0.0543 \\
(0.0065)^{*} \\
* *\end{array}$ & $\begin{array}{l}0.0654 \\
0.3324\end{array}$ & $\begin{array}{l}0.0432 \\
(0.0322)^{*} \\
*\end{array}$ & 1.000 & & \\
\hline Issue Size & $\begin{array}{l}0.0480 \\
(0.1690)\end{array}$ & $\begin{array}{l}-0.0212 \\
(0.5431)\end{array}$ & $\begin{array}{l}0.0057 \\
(0.8700)\end{array}$ & $\begin{array}{l}0.0268 \\
(0.4432)\end{array}$ & $\begin{array}{l}0.1655 \\
(0.0000 \\
)^{* * *}\end{array}$ & $\begin{array}{l}-0.0751 \\
(0.0312)^{*} \\
*\end{array}$ & $\begin{array}{l}-0.0174 \\
(0.6175)\end{array}$ & 1.000 & \\
\hline Leverage & $\begin{array}{l}0.0865 \\
(0.0345)^{* *}\end{array}$ & $\begin{array}{l}-0.0643 \\
(0.0778)^{*}\end{array}$ & $\begin{array}{l}-0.0083 \\
(0.6753)\end{array}$ & $\begin{array}{l}0.1045 \\
(0.0123)^{*} \\
* *\end{array}$ & $\begin{array}{l}0.0001 \\
(0.8654 \\
)\end{array}$ & $\begin{array}{l}-0.1144 \\
(0.0064) * \\
* *\end{array}$ & $\begin{array}{l}-0.0539 \\
(0.1345)\end{array}$ & $\begin{array}{l}0.004 \\
5 \\
(0.97 \\
53)\end{array}$ & $\begin{array}{l}1.00 \\
0\end{array}$ \\
\hline
\end{tabular}

To test our first hypothesis, we propose to run the mean comparison tests. To do so, we split our sample into two sub groups: a first group of companies that have a positive operating cash balance and a second group 
that includes the remaining ones. The T-test output confirms our hypothesis since the mean for the first group (4.7) is greater than the mean of the second group (4.1). Moreover, the T-Test and the Wilcoxon-Mann-Whitney test confirm that difference between the two means is significantly different from zero (5\% significance level).

This implies that the companies belonging to the positive operating cash group enjoys higher credit ratings.

\begin{tabular}{|l|l|l|l|l|l|}
\hline Variable & $\begin{array}{l}\text { Bonds } \\
\text { Ratings }\end{array}$ & $\begin{array}{l}\text { Creditors' } \\
\text { Rights }\end{array}$ & $\begin{array}{l}\text { Public } \\
\text { Registry }\end{array}$ & $\begin{array}{l}\text { Efficiency of } \\
\text { Bankruptcy } \\
\text { Process }\end{array}$ & $\begin{array}{l}\text { News } \\
\text { Circulation }\end{array}$ \\
\hline Bonds Ratings & 1.000 & & & & \\
\hline $\begin{array}{l}\text { Creditors' } \\
\text { Rights }\end{array}$ & $\begin{array}{l}0.1567 \\
(0.0000)^{* * *}\end{array}$ & 1.000 & & & \\
\hline Public Registry & $\begin{array}{l}0.1556 \\
(0.0003)^{* * *}\end{array}$ & -0.3453 & 1.000 & & \\
\hline $\begin{array}{l}\text { Efficiency of } \\
\text { Bankruptcy } \\
\text { Process }\end{array}$ & $\begin{array}{l}0.0554 \\
(0.4325)\end{array}$ & $\begin{array}{l}0.5643 \\
(0.0000)^{* * * *}\end{array}$ & $\begin{array}{l}-0.8765 \\
(0.0000)^{* * *}\end{array}$ & 1.000 & \\
\hline $\begin{array}{l}\text { News } \\
\text { Circulation }\end{array}$ & $\begin{array}{l}0.1255 \\
(0.0000)^{* * *}\end{array}$ & $\begin{array}{l}0.6543 \\
(0.0000)^{* * * *}\end{array}$ & $\begin{array}{l}-0.1245 \\
(0.0000)^{* * * *}\end{array}$ & $\begin{array}{l}0.6543 \\
(0.0000)^{* * *}\end{array}$ & 1.000 \\
\hline
\end{tabular}

Panel A from Table 4 identifies the results for the Ordered Probit estimation for the bonds ratings. Most of the results were as we expected before running the regression. The results imply that the positive operating cash balance have a positive significant impact on the bonds ratings ( +0.4 at a significance level of 5\%). This support our first hypothesis since being able to generate cash from company's main operations increases the probability of enabling the company to have higher bonds ratings. The company profitability and size have a positive significant impact on the bonds ratings. On the other hand, the convertible bonds option is the only issue variable which significantly impacts the bonds ratings of companies positively. The other issue and issuer variables have no significant impact on the bonds ratings.

The results for the other control variables have met our expectations since they affect the bond ratings positively at significant levels. The total increase in cash (from all activities) affects positively $(+0.3)$ the bonds ratings at significance level of 5\%. This finding approves our second hypothesis since we have found that higher positive cash balances scores leads to higher bonds ratings.

The table gives the output for the Ordered Probit Regression of the Bond Ratings as being the dependent variable. The variables that are listed below are: Bond Ratings which is an ordinal number that ranges from 1 to 7 as the later being the highest rating and the former the lowest rating. 
Company's cash: a dummy variable that assigns 1 to companys that have a positive cash operating balance and 0 otherwise. Company Profitability: the company profitability measured in term of its return on assets. Company Size: the total assets were used to get the size of the companys that are included in the sample. Company Risk: it is measured by the standard deviation of net income. Bonds Maturity: the average maturity for the bonds portfolio issued by a company; weights were assigned on the basis of the size of the issuance to the total issuances. Convertible Provisions: a dummy variable that gives 1 to companys with the convertible option and 0 otherwise. Issue Size: it represents the size of the issuance in term of dollars. Leverage: the company leverage is measured by the debt to equity ratio. Concerning the other variables, more description is given in table 1 . The stars that appear in the tables mean the following: $* * *$ for a significance that is lower than $1 \%, * *$ and $*$ are for a significance that is lower than $5 \%$ and $10 \%$ respectively.

Table 4: The Effect of company's operating cash on Bond ratings

\begin{tabular}{|l|l|l|}
\hline $\begin{array}{l}\text { Dependent Variable } \\
\text { Bonds ratings }\end{array}$ & Expected Sign & Model \\
\hline Company's operating cash position & + & $0.341(0.044)^{* *}$ \\
\hline Company Profitability & + & $0.0123(0.005)^{* * *}$ \\
\hline Company Size (in billions of U.S Dollars) & + & $55.6(0.000)^{* * *}$ \\
\hline Company risk (in millions of U.S Dollars) & - & $-232(0.765)$ \\
\hline Bonds Maturity & - & $-0.543(0.345)$ \\
\hline Convertible Provisions & + & $0.600(0.000)^{* * *}$ \\
\hline Issue Size & - & $3.65 \times 10^{9}(0.678)$ \\
\hline Leverage & - & $-0.000(0.234)$ \\
\hline Creditors Rights & + & $0.244(0.056)^{* *}$ \\
\hline Public Registry & + & $1.432(0.000)^{* * *}$ \\
\hline Bankruptcy Efficiency & + & $0.006(0.003)^{* * *}$ \\
\hline News Circulation & + & $0.235(0.075)^{*}$ \\
\hline Manufacturing & & $0.344(0.333)$ \\
\hline Trades & & $-0.008(0.876)$ \\
\hline Finance & & $0.788(0.003)^{* * *}$ \\
\hline Utility & & $0.624(0.054)^{*}$ \\
\hline $\mathrm{N}$ & & 600 \\
\hline Pseudo R & & $13.67 \%$ \\
\hline LR - Chi ${ }^{2}$ & & 234.77 \\
\hline Significance & & $(0.0000)^{* * *}$ \\
\hline
\end{tabular}

Jenzazi (2010) found that the bond rating is positively affected by the company's liquidity but his research was limited to the overall cash position and took into consideration companies operating in the U.S only. Our findings suggest that, on an international scale, the bond ratings are significantly impacted by operating liquidity. Having positive operating cash balance, allows the company to enjoy a relatively higher bond ratings 
compared to companies with negative operating cash balances. As a result, the costs for incurring debts (in the form of bonds) are lowered since creditors ask for relatively lower premiums for lending their money.

\section{Limitations}

We face one major limitation at the level of the sample representativeness. Actually, we took the data on the bonds ratings from the F-Database and the data on the auditors from the W-Database. The matching of the two databases provided us with 600 observations that follow the distribution which is described in table 2. This fact could affect the representativeness of our sample.

\section{Conclusion}

In our research we study the relationship between the companies' liquidity and the bonds ratings on an international scale. Our sample includes 600 companies from 26 different countries and the data is taken over a period of 10 years (from 2002 to 2012). The results of the Ordered Probit regression approve our expectations. In other words, we prove that when a company has a positive operating cash balance, the probability of having higher ratings for its bonds increases. This evidence suggests that the company's liquidity and more precisely the extent to which companies are able to generate cash from their mean operations affects their cost of debt; having a positive operating cash position allows the company to enjoy relatively higher ratings for its bonds and this leads to relatively lower costs of debt (in the form of bonds). The outcome of this research will add to the existing literature since no previous studies related to that field were done on a national or international scale. Having positive operating cash balance implies that the company is doing well in its main operations, enabling it to enjoy relatively lower cost of debt and this can increase its profitability and earnings.

Previous studies had used the change in total cash balance as a proxy for liquidity; however, many companies are able to inflate their cash position using the investing and financing activities. Once limiting the proxy to only the cash generated from operating activities, we are already excluding different sources of cash that can manipulate the results. Moreover, even within the operating cash, there is still some room for manipulation and misleading. Sometimes expenses such as depreciation, can be considered as a source for operating cash; however in reality it is not; instead, it is only a non-cash expense and that is why it is considered as a source of cash; furthermore, increases in accounts payable are also considered as sources of cash under the indirect method, however in reality they are not a source of 
cash, instead, it is just postponing the payment of current expenses to an upcoming period.

\section{References:}

Adam E., Max H. and Marlene P. "Disaggregating operating and financial activities: implications for forecasts of profitability" Review of Accounting Studies Volume 19, Issue 1, pp 328-362

Defond, M. and J. Jiambalvo. "Debt covenant violation and manipulation of accruals." Journal of Accounting and Economics 17 (1994): 145-176.

Bhojraj, S. and P. Sengupta, (2003), "Effect of Corporate Governance on Bond Ratings and Yields: The Role of Institutional Investors and the Outside Directors." The Journal of Business, 76, pp. 455-475..

Bhattacharya, N., F. Ecker, P. Olsson and K. Schipper (2009), "Direct and mediated associations among earnings quality, information asymmetry and the cost of equity," Working Paper, Fuqua School of Business, Duke University.

Boubakri, N., and Ghouma, H., (2007), "Creditor Rights Protection, Ultimate Ownership and the Debt Financing Costs and Ratings: International Evidence.

Brennan, M., T. Chordia and A. Subrahmanyam (1998), "Alternative factor specifi cations, security characteristics and the cross-section of expected stock returns," Journal of Financial Economics, 49, 345-373.

Callen, J.L., and D. Segal. 2005. Empirical tests of the Feltham-Ohlson (1995) model. Review of Accounting Studies 10: 409-429.

Dechow, P. M., R. G. Sloan, and M. T. Soliman. Implied equity duration: A new measure of equity risk. Review of Accounting Studies 9, 197-228.

Dechow, P.M., and W. Ge. 2006. The persistence of earnings and cash flows and the role of special items: Implications for the accrual anomaly. Review of Accounting Studies11(2/3): 253-296.

Gilson, S. C. "Transactions costs and capital structure choice: Evidence from financially distressed firms." Journal of Finance 52 (1997): 161-196.

Frankel, R. 2009. Discussion of 'Are special items informative about future profit margins?' Review of Accounting Studies 14: 237-245

Hamdi B. Hatem G. and El-Mehdi A. (2014) "Auditor Choice and Corporate Bond Ratings: International Evidence" International Journal of Economics and Finance; Vol. 6, No. 1; 2014

Kasznik, R. (1999), "On the association between voluntary disclosure and earnings management," Journal of Accounting Research, 37 (1999), 57-81.

Kim, O. and R. E. Verrecchia (1994), "Market liquidity and volume around earnings announcements," Journal of Accounting and Economics, 17, 41-67. 
Klock, M., S. Mansi and W. Maxwell, (2005), "Does corporate governance matter to bondholders." Journal of Financial and Quantitative Analysis, 40, 4, pp. 693-720.

Kubota, K. and H. Takehara (2009), "Information based trade, the PIN variable, and portfolio style differences: Evidence from Tokyo stock exchange fi rms," Pacifi c-Basin Finance Journal, 17, 319-337.

Nissim, D., and S.H. Penman. 2001. Ratio analysis and equity valuation: From research to practice. Review of Accounting Studies 6(1): 109-154.

Sengupta, P., (1998), "Corporate Disclosure Quality and the Cost of Debt." The Accounting Review, 73, pp. 459-474.

Shleifer, A. and Vishny, R., (1997), "A Survey of Corporate Governance". Journal of Finance, vol. 52, issue 2

Watts, R. L. and J. L. Zimmerman. Positive Accounting Theory. Englewood Cliffs, N. J.: Prentice Hall, 1986.

Willenborg, M. "Empirical Ana lysis of the Economic Demand for Auditing in the Initial Public Offering Market." Journal of Accounting Research 37 (1999): 225-238

Zhiyan c. , Ganapathi S. Narayanamoorthy. "Accounting and litigation risk: evidence from Directors' and Officers' insurance pricing" Review of accounting studies, Volume 19, Issue 1 (2014) :1-44

Appendix A: S\&P Credit Ratings Conversion

\begin{tabular}{|l|l|l|l|l|l|l|l|}
\hline $\begin{array}{l}\text { S\&P } \\
\text { Bonds } \\
\text { Ratings }\end{array}$ & $\begin{array}{l}\text { From D } \\
\text { to CCC+ }\end{array}$ & $\begin{array}{l}\text { From B- } \\
\text { to B+ }\end{array}$ & $\begin{array}{l}\text { From } \\
\text { BB- to } \\
\text { BB+ }\end{array}$ & $\begin{array}{l}\text { From } \\
\text { BBB- to } \\
\text { BBB+ }\end{array}$ & $\begin{array}{l}\text { From } \\
\text { A- to } \\
\text { A+ }\end{array}$ & $\begin{array}{l}\text { From } \\
\text { AA- to } \\
\text { AA+ }\end{array}$ & AAA \\
\hline $\begin{array}{l}\text { New } \\
\text { Ratings }\end{array}$ & 1 & 2 & 3 & 4 & 5 & 6 & 7 \\
\hline
\end{tabular}

